
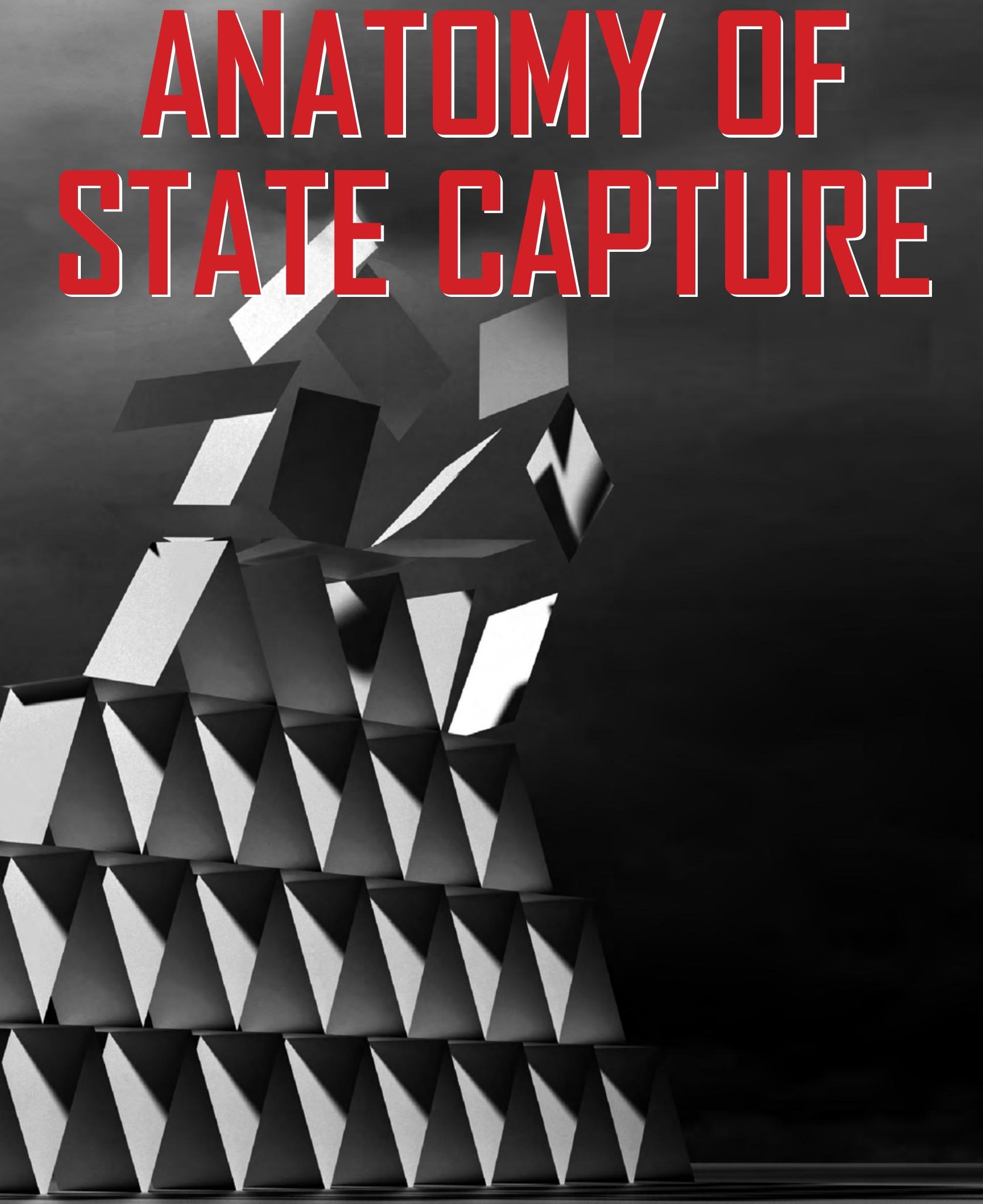

Nina Callaghan, Rabyn Foley and Mark Swilling (EDITuRS) 


\section{FROM THE MARGINS TO THE CENTRE: PRIVATE SECTOR'S ROLE IN STATE CAPTURE}

Michael Marchant and Mamello Mosiana

\subsection{INTRODUCTION}

In the South African imagination, the phenomenon of state capture has been largely relegated to the story of corrupt actors within the executive branch of government, dubious middlemen, and the disintegration of governance at state-owned enterprises. It remains crucial to analyse the public sector, and the vulnerability of public procurement processes at SOEs to manipulation for personal gain. It is similarly important to interrogate the causes of institutional weakness in the state that contributes to governance failure. Yet, this analysis should not exclude the role of South African and international private corporations. These actors have been both enablers and active participants in corruption. Any analysis of state capture that does not account for the private sector's role is incomplete.

Private professionals play a key role in constructing a global architecture to move and obscure the proceeds of grand corruption, and in effect, legitimise these illicit gains (Radu, 2019). Without the facilitation of money laundering by private-sector professionals, it would not be possible for those engaged in the looting of SOEs to profit from their crimes. Money laundering requires the active assistance or wilful ignorance of banks, company formation agents, auditors, lawyers and consultants. While the façade of legitimacy enjoyed by these professions shields them from meaningful scrutiny, they have regularly made the decision to privilege profit over their legal and ethical responsibilities. In the case of state capture in South Africa, these professionals were on the front-line of observing that their systems and services were being used to enable grand theft. Yet they failed to act, placing profit above their legal duties.

In this chapter, we move these actors to the centre of state capture analysis. In doing so, we analyse the systemic role of private corporations as enablers of grand corruption, including the looting that defined the particular era of 'state capture' under the Zuma administration. The chapter will then use this framework to explore the role of these private 'enablers' in the capture and looting of Transnet. 


\subsection{GLOBAL FINANCE: ENABLING GRAND CORRUPTION}

There are a set of myths that have hindered the interrogation of how the private sector assists money-laundering for the corrupt, terror groups, drug traffickers, authoritarian regimes, and those involved in organised crime. The first myth is that corruption is a problem related only to governments, and second that corporate crime ought to be separated from public sector crime (Open Secrets, 2018, p. 6). These myth can be dispelled by the evidence found in the Panama Papers and Luxembourg Leaks both of which reveal a network of bankers, accountants and lawyers engaged in and assisting corrupt officials and corporations around the world (Ballard, 2018). Their systems move and conceal billions in corrupt proceeds. Closer to home, the twodecade long corporate fraud at Steinhoff was pulled off through a network of secret front companies around the world that allowed Markus Jooste and other Steinhoff executives to stash wealth in secret (McKune, amaBhungane \& Thomson, 2018).

South Africa's history evidences the confluence of private and public interests in profiting from a crime against humanity. Integral to the survival and violence of the apartheid regime, was a network of international banks and arms companies, predominantly in Europe, that collaborated with the government in contravention of UN Sanctions (Van Vuuren, 2017). Foreshadowing contemporary stories of state capture, these crimes were achieved through anonymous shell companies and banks willing to facilitate their illicit payments.

The term 'state capture' has been used most recently and popularly by the World Bank to describe the 'capture' of state institutions in former soviet-bloc countries by private interests, including politically connected corporations (Kaufmann, Hellman, Jones \& Schankerman, 2000; Yakovlev \& Zhuravskaya, 2009). The uncovering of the Russian Laundromat in 2014 (OCCRP, 2017), the Troika Laundromat in 2019 (Radu, 2019) and the burgeoning Danske Bank "scandal" has illustrated how corrupt state actors laundered money through Eastern European banks, who in turn moved this money extensively through European and American banks (OCCRP, 2018). Secretive corporate vehicles in the UK and its crown dependencies are equally important to this financial architecture.

Yet, as has been the case in South Africa, analysis of the capture of former USSR states has been confined to the names of political actors like Russian President, Vladimir Putin, and Azerbaijani President, Ilham Aliyev. The evidence shows that, without some of the world's largest and wealthiest banks (including Danske Bank and Deutsche Bank) and anonymous corporate vehicles set up in the United Kingdom, these actors would be unable to disguise, legitimise and ultimately enjoy their ill-gotten gains (Bullough, 2018). Therefore, one cannot say that the capture of one state is geographically 
confined to its borders. Rather, the evidence shows that grand corruption involves the extensive involvement of a secretive global financial architecture.

\subsection{THE ROLE OF BANKS}

Money laundering is a lucrative industry. The United Nations Office for Drugs and Crime (UNODC) suggests that up to $\$ 2 \mathrm{tn}$ is "laundered" every year - a staggering $5 \%$ of global GDP (Katz, 2019). Global banks are at the heart of this system. There are a range of hard and soft law requirements for countries and financial institutions to combat the scourge of money laundering. In most jurisdictions, including South Africa, it is a requirement for all banks to institute and enforce anti-money laundering (AML) systems, including the requirement to Know Your Customer (KYC). South Africa is also one of 36 member jurisdictions of the Financial Action Task Force (FATF), an intergovernmental body established in 1989 to combat money laundering (FATF, 2019).

The FATF's typology of money laundering is as follows: illicit funds are "placed" into the financial system by deposit (often through multiple smaller transactions) into a bank account, this is called "smurfing". Then, the money is "layered" which involves moving assets through multiple accounts (often in different jurisdictions and in the name of front companies) to make them untraceable (Open Secrets, 2018, p. 28). Banks are crucial to the placement and layering phases of money laundering (FATF, 2019). Once the money is cycled within the global banking system, it is hard to distinguish 'dirty' money from 'clean' money, thus the money is 'laundered'. This typology will be immediately familiar to those who have seen how the Gupta network laundered kickbacks from corrupt deals through the legitimate banking system.

Under South Africa's Financial Intelligence Centre (FIC) Act, banks are required to investigate the identity of their clients and consider "the background and purpose of all complex, unusual large transactions, and all unusual patterns of transactions, which have no apparent business or lawful purpose" (Republic of South Africa, 2001, section $21 \mathrm{c}$ (a)(ii)). This is in line with FATF recommendations.

These requirements are shared across most jurisdictions today. Yet in many cases in the past decade, banks appear to have fundamentally failed to fulfil these most basic anti-money laundering requirements.

Standard Bank, for example, held accounts for Gupta shell company Homix, which has been implicated in laundering kickbacks related to several corrupt SOE contracts, including receiving a multi-million 'kickback' from Neotel to access a lucrative contract with Transnet (Bezuidenhout, 2019). South African Reserve Bank official Mr Shiwa Mazibuko testified to the Zondo Commission of Inquiry that the Homix 
transactions raised almost every single red flag for money laundering and that it was inexplicable that Standard Bank did not pick up on the risk. Mazibuko also said that, if Standard Bank did pick up on these risks, it did not act on the warning signs (Zondo Commission, 2019).

Standard Bank is not the only bank implicated in such failures. Most of South Africa's big banks and many global banks facilitated money flows linked to the plunder of SOEs. The Estina dairy project in the Free State is one such example, it should have alarmed banks that a small shell company (Estina) suddenly started receiving large sums from the Free State Department of Agriculture for a dairy project. Most of this money was diverted through Dubai-based shell companies, and some was used to pay for the luxurious Gupta wedding at Sun City. Despite numerous red flags, First National Bank, Standard Bank, and the Bank of Baroda (amongst other international banks) all facilitated the money flows that enabled this (Pather, 2018).

These local failures are indicative of systemic global failures in the banking system. Despite burgeoning legal requirements to combat money laundering - breaches and failures of these systems are on the rise. In 2018 alone, Goldman Sachs (US), Union Bank of Switzerland, Rabobank (Netherlands) and US Bancorp all faced litigation and penalties for failing to adhere to their AML systems (Neale, 2019). In the same year, the story of the biggest ever global money laundering crime broke: Danske Bank had laundered \$230bn between 2007 and 2015. Much of the money had suspicious or corrupt origins in Russia and elsewhere in Eastern Europe, and had not just moved through Danske, but also through Deutsche bank, Swedbank and Nordea (Schwartzkopff, 2019).

Despite renewed efforts to fine banks for AML breaches, banks continue to participate in money laundering because the profits far exceed possible penalties. A 2012, \$1.9bn fine for HSBC's laundering of money for drug cartels Sinaloa and Norte del Valle, though the largest for a bank at the time, was worth less than a month of the bank's profits (Keefe, 2017). Banks profit significantly from illicit transactions, and thus have substantial incentives to ignore suspicious transactions. Global evidence suggests that fines for money laundering are not deterrents. If anything, they are becoming the cost of doing business.

Nor are bankers the only professionals failing to exercise the due diligence required of them. The so-called 'Big 4' audit firms (Deloitte, PwC, EY and KPMG) are increasingly implicated in assisting corporations to siphon money offshore, and the evidence suggests that as profits from their consulting arms grow, audit quality is in decline. KPMG, in particular, has been implicated in several scandals linked to state capture. This includes a failure to report glaring reportable irregularities when it audited 
Linkway Trading, the most important conduit for the laundering of funds linked to the Estina dairy farm scandal (Bloomberg, 2018). KPMG's audits of Linkway Trading were riddled with errors, including ignoring the fact that R30m used for the Gupta wedding at Sun City passed through Linkway's bank account and constituted 55\% of Linkway's revenue (Khumalo, 2018). Instead of flagging this irregularity, the auditors were complicit in hiding it, passing the wedding off as an expense that could reduce Linkway's tax burden. Arguably, this action alone goes far beyond 'facilitating' corruption, rather showing active complicity of KPMG in the looting of the state.

\subsection{FRONT COMPANIES FOR SALE: COMPANY FORMATION AGENTS THAT SELL SECRECY}

In addition to the failures of banks to counter money laundering, there is a second issue that lies at the core of money laundering, namely the ease with which corrupt elites and organised criminal networks can procure secretive 'front companies'. Front or shell companies are corporate vehicles that conceal the true owners or beneficiaries while providing a thin veneer of legitimate activity (Transparency International UK, 2017). It is usually these entities that hold the bank accounts used to launder illicit gains. The examples stated above all reference shell companies and their role in laundering corrupt proceeds.

In 2011, the United Nations Stolen Asset Recovery Initiative (StAR) undertook a review of over 150 cases of 'grand corruption' around the globe. Unsurprisingly, it found that in, almost all cases, a corporate vehicle (such as a company or trust) was misused to launder the proceeds of crime (Van der Does de Willebois, Halter, Harrison, Park \& Sharman, 2017). In most cases, beneficial ownership information of the company was not available, however, if it was available, the company was almost always "established or managed by a professional intermediary" (Van der Does de Willebois et al., 2017). These 'company service providers' (also called 'company formation agents') are staffed by lawyers, chartered accountants and other professionals. They specialise in quickly setting up a company with a bank account for any client with very few questions asked.

Some jurisdictions around the world 'specialise' in the supply of secret corporate vehicles - the city of London is a perfect example and attracts vast inflows of proceeds of corruption as a result. ${ }^{1}$ These jurisdictions profit from attracting this money, while undermining governance and the rule of law elsewhere by allowing illicit flows to be moved and stored in secret (Cobham, Janský \& Meinzer, 2015). Evidence presented to the Zondo Commission of Inquiry indicates that to profit from corrupt procurement

1 UK LLPs (Limited Liability Partnerships) funnel billions of US dollars of illicit origin through dormant front companies set up by company agents in London. 
deals, those in the so-called 'state capture network' registered multiple shell companies in both Dubai and Hong Kong. Hong Kong and Dubai are ranked in the top 10 most secretive jurisdictions in the world, predominantly because of the ease with which secrecy is preserved and corporate vehicles can be abused to launder illicit proceeds (Tax Justice Network, 2018b). Unsurprisingly, many of the registered offices of state capture network companies in Dubai and Hong Kong were often vacant and had no active business; many only existed on paper but received large sums of South African public money that originated from corrupt deals (Anderson, 2017).

The modern global economy sees billions funnelled through registered companies with no actual staff or activities whatsoever. For example, the Luxembourg Leaks revealed how PwC had secured secret deals to eliminate tax for hundreds of multinational enterprises, through 1600 corporations all ostensibly housed in one small building in Luxembourg - a notorious tax haven (ICIJ, 2014).

It is not always necessary to go offshore to notorious tax havens to achieve anonymity. Many illicit transactions linked to state capture were funnelled through front companies registered in South Africa. Here too it is far too easy to buy a readymade shell company that is susceptible to abuse. South Africa also lags behind many countries in terms of our requirements to have publicly available information on beneficial ownership. This means that those involved in criminality here can purchase a corporate vehicle with a 'nominee director' (often provided by the company agent as well) and use it to conduct illicit business without having their identity publicly linked to it.

The ease with which one can procure a shelf company in South Africa whose beneficial ownership remains secret should be a matter of grave concern. In light of the exhaustive evidence pointing to the abuse of these corporate vehicles for the purposes of fraud and corruption, there is an urgent need for greater corporate transparency in South Africa. This includes the need to amend the Companies Amendment Bill to include a public registry of beneficial ownership (McGregor, 2019). Unfortunately, the latest draft of the Bill (tabled in 2018) did not include these recommendations, despite the global trend towards including beneficial ownership transparency as an essential tool in fighting corruption and corporate crimes (McGregor, 2019).

\subsection{CASE STUDY: ENABLING THE LOOTING OF TRANSNET}

The now infamous procurement of 1064 locomotives by Transnet as part of their modernisation process is one of the most glaring examples of the sheer scale of the financial cost of state capture. The contract and its related costs eventually totalled around R55bn. This is R16bn more than initially projected by Transnet. Subsequent 
forensic investigations have surmised that the R16bn escalation can be explained by a manipulated procurement process designed to enrich a few individuals and corporations linked to the Gupta family (Werksmans Attorneys, 2017).

The Werksmans Attorneys Report, procured by Transnet, identifies the Transnet board of directors as being potentially liable for gross negligence in the loss of billions of rand (Werksmans Attorneys, 2017, p. 107). These directors should be declared delinquent and face criminal sanction where appropriate.

But the private actors who facilitated and participated in these activities should similarly be interrogated and sanctioned.

\subsubsection{China South Rail: How to Launder Kickbacks}

One of the more nefarious aspects of the 1064 locomotive deal was the contract with China South Rail (CSR) for the delivery of 359 locomotives for South Africa's trains. The 359 locomotives were delivered late and did not work when they arrived, but the deal was still worth around R20bn. Over $20 \%$ of that was set aside for 'commissions' to be paid to companies linked to Salim Essa, a known Gupta associate, purportedly for being CSR's 'supplier development'2 partner (Sharife, 2017). This meant that Transnet had to foot the bill for nearly R5bn in what appear to be kickbacks, as the firms paid appear not to have actually provided any meaningful services. These payments were made predominantly to offshore companies in secrecy jurisdictions and routed through numerous accounts so as to make tracking the money more difficult.

CSR had already done deals with Transnet before the purchase of the 359 locomotives. In those earlier deals, kickbacks were laundered through Dubai. Significant sums of money paid to CSR were funnelled through two companies based in the UAE; JJ Trading FZE (JJT) and Century General Trading (CGT). CSR's 'consulting fee' on one of the procurement deals went to CGT while the fees related to the other deals went to JJT (amaBhungane \& Scorpio, 2017). It has never been clear what services these companies provided that would have explained these fees; 'consulting fees' are a common red herring for corruption or money laundering and have been widely cited as the reason for the payment of numerous Gupta shelf companies. A whistle-blower with knowledge of the deal told amaBhungane that JJ Trading was essentially a front for the Guptas: it signed the original agreements with CSR but remitted proceeds to Gupta-linked companies (amaBhungane \& Scorpio, 2017).

2 South African law requires public procurement to consider transformation and empowerment requirements when choosing suppliers. In the case of state capture, these requirements were often abused by paying front companies kick-backs and presenting them as 'empowerment partners' without any actual work being done. 
CGT and JJT are registered in the UAE Free Zone, a jurisdiction notorious for secrecy and turning a blind eye to illicit and criminal money. When journalists travelled to Dubai to find the offices of the companies that had received billions of rands in fees, they unsurprisingly found nothing. While they were not allowed in to the complex where JJT was registered, a security guard said that no such company existed there (Van Zyl, 2017).

Crucially, by the time of the deal for the 359 locomotives, the locus of the money laundering network linked to the CSR deal moved from Dubai to front companies in Hong Kong. Thanks to the dedicated work of investigative journalists, the public is now aware that around R1.5bn was paid to the accounts of two companies linked to Salim Essa. The two firms - Tequesta and Regiments Asia - were set up in Hong Kong on exactly the same day and registered to the same address, likely by the same company formation agent.

Soon after registration, both companies started receiving multiple large inflows of money (Sharife, 2017). As mentioned above, Hong Kong is one of the most secretive jurisdictions in the world, it is ranked 4 th by the Financial Secrecy Index. Hong Kong provides a wide range of 'offshore services' ranging from tax avoidance to the provision of opaque companies that can be used for clandestine purposes, without publicly disclosing beneficial ownership (Tax Justice Network, 2018a).

Salim Essa registered Tequesta in Hong Kong in June 2014 and signed the contract with CSR in May 2015, under which the 21\% 'fee' for the 359 locomotives became due to Tequesta (amaBhungane \& Scorpio, 2017). Tequesta was required to "play [an] active role in providing advisory services in respect of the Project, Business development and BEE structuring and management in the country" (Tequesta Group Limited, 2015, para. b). In return for providing these services, Tequesta would be entitled to the $21 \%$ fee. Of course, it made no sense that a company set up months before and with no discernible infrastructure would be a party to such a large contract.

According to banking data obtained by journalists at the OCCRP, R5.3bn was paid by CSR into two accounts: the first was Tequesta's HSBC account, which received $\mathrm{R} 651 \mathrm{~m}$ between June and October 2015 (Sharife, 2017). The other payment was made to the HSBC account of Regiments Asia (Sharife, 2017). CSR's payments to Tequesta and Regiments Asia accounted for $90 \%$ of the credits to these accounts (Sharife, 2017). Yet these funds did not remain in these two companies' bank accounts for long. More than $\$ 100 \mathrm{~m}$ was transferred from Regiments Asia to two dozen companies, mostly via HSBC, with other banks in Johannesburg, Dubai, and the USA playing a part in the movement of money (Sharife, 2017). 
The fact that these companies received such large sums in a very narrow period, and the tendency for large sums to be deposited and immediately moved on, the OCCRP concluded that these companies were shell corporations (Sharife, 2017). These payments by Regiments Asia were all made between late 2014 and February 2017 the bulk of these transfers occurring in February 2017 (Sharife, 2017). The same shell companies also received payments from Tequesta (Sharife, 2017).

\subsubsection{HSBC}

Global banking giant HSBC provided the banking facilities for both the Dubai based laundering network (CGT and JJT) and the latter system set up in Hong Kong (Tequesta and Regiments Asia). HSBC actually did flag suspicious transactions that had flowed between CGT and JJT and other shell companies, but three years too late. By then, CSR had already paid JJT and CGT R1.6bn of the intended R5.3bn - and there is substantial evidence of this then flowing into the Guptas' other offshore accounts (Stenhauser \& Patrick, 2017). HSBC has denied culpability for its poor moneylaundering checks on CGT and JJT, and stated: "To the best of our knowledge, HSBC previously exited, is in the process of exiting, or never had a banking relationship with JJ Trading [or] Century General Trading” (Stenhauser \& Patrick, 2017).

HSBC is a sprawling mega-corporation comprising entities in 71 countries, it is also currently the biggest bank in Europe (Garcia-Bernardo, Fichtner, Takes \& Heemskerk, 2017). It is incredibly well resourced and ostensibly has a dedicated compliance department to fulfil its legal anti-money laundering duties. Thus, HSBC's vague answers on their AML failures are simply not good enough. HSBC should account for how it failed to identify the overtly suspicious transactions immediately and close the accounts.

HSBC also should have applied the necessary due diligence to 'know their customer' before allowing Salim Essa to establish bank accounts and immediately channel over R1bn through them and on to other shell companies. Yet these controls failed. Using the typical money laundering tricks of smurfing and layering, the money was sent regularly in smaller amounts, and quickly paid on by Tequesta and Regiments Asia to a number of other shell companies that were receiving this money despite having no visible employees or operations. By this point, payments had not just passed through HSBC accounts but through a range of banks from South Africa to Dubai and the United States (Davies, 2017).

Importantly, smurfing and layering are common money laundering manoeuvres, and so should have been identified by a bank as well-resourced as HSBC. Not only were the companies registered at the same time by Essa, an individual already alleged 
to be a Gupta frontman, but within months of their formation they were receiving millions of dollars in payments, purportedly for 'advisory services'. The payments into the accounts came from Chinese SOEs and were the only sources of income for these accounts. Any bank should want to know what sort of legitimate business, newly formed and with no discernible infrastructure receives such large payments from four related state entities, without receiving any income from any other parties. In addition, a red flag for money laundering should be raised when large sums are received and immediately dissipated again.

Finally, HSBC had already acted in relation to some Gupta-linked accounts on the basis of what it had deemed suspicious activity. According to a statement released by HSBC in November 2017, it felt compelled to close a number of front companies linked to the Guptas in 2014 (Tax Justice Network, 2018a).

In light of all of this, it is inexplicable that no attempt was made to shut these accounts, or, at the very least, investigate and establish what connections the Tequesta and Regiments Asia accounts had with the Gupta family or other South African corruption scandals. One possible reason for these failures is that tricky or high-risk accounts often bring in larger bank fees, providing a possible motivation behind HSBC not reporting, investigating or shutting these accounts.

Either the banks and authorities did not pick up on this conspicuously suspicious activity, or if they did, they refused to act and stop it. Reportedly, when compliance departments did flag suspicious transactions, nothing was done to stop the process. Both in the case of Hong Kong and HSBC, there appears to be an approach that puts profit above all other obligations. In this world of financial secrecy and rapid money flows, regulation and ultimately the provision of basic services to South Africans was sacrificed for the sake of profit.

\subsubsection{China North Rail}

While the story of CSR's kickbacks are egregious and have dominated the headlines, a lesser told story is the role of a South African front company in facilitating kickbacks linked to Transnet's dubious contract with China North Rail (CNR) - CSR's sister company.

Business Expansion Structured Products (BEX) was first registered in 2009 and is registered to an address in the affluent Melrose Arch in Johannesburg (CIPC, 2019). The company is in the process of deregistration but still shows that it has two 'active principals' - Taufique Hasware (another known Gupta frontman), and Legal Frontiers (Corporate Services) CC (CIPC, 2019). BEX was central to an inflated deal that saw 
CNR charge Transnet over R600m simply to move a building site from Pretoria to Durban. Ultimately, BEX earned a R66m 'commission' for itself from a massively inflated contract for the relocation of the site (Pillay \& Prins, 2018). As has been alleged by CNR's South African partners to the Commission, "there was absolutely no justification for Transnet to agree to pay China North Rail SA (CNR SA), contracted to supply 232 diesel locomotives, close to R700m for moving a yet-to-be operational plant" (Sole, 2018).

Subsequent investigations have shown that BEX was ultimately controlled and used by Salim Essa, a known Gupta Lieutenant, to extract a lucrative kickback. Yet Essa gave instructions from afar and was not a listed director of BEX, even though he was clearly the company's directing mind and beneficial owner. Salim Essa was able to set the company up and operate it through a South African Close Corporation - Legal Frontiers (CC).

Legal Frontiers has admitted that it 'sold' BEX as a standard shelf company together with a VAT number, a nominee director to act as signatory, and a Standard Bank account - all to Salim Essa, for a fee (Daily Maverick, 2018). When asked why instructions came from Salim Essa instead of the named director Taufique Hasware (whom Legal Frontiers never met), the firm insisted that this was not unusual (Tugendhaft Wapnick Banchetti \& Partners, 2018). Their legal representative, writing to journalists investigating the story, insisted that the kinds of services provided by Legal Frontiers were standard practice in South Africa and that there was nothing 'irregular' in their behaviour:

\begin{abstract}
As part of its stock-in-trade, Legal Frontiers maintains a number of shelfcompanies, which it makes available to clients at request and on short notice. The process involves Legal Frontiers ... appointing its representative as director and shareholder for each such shelf-company ... Bank accounts are established prior to the company being disposed of and where at that time the signatory is a representative of Legal Frontiers ... There is nothing irregular in the process as set out a foregoing, which is common in any number of company secretarial firms in the Republic. (Sole, 2018)
\end{abstract}

The fact that such a process is viewed as standard procedure is cause for concern. These kinds of entities operate with little scrutiny, and the professionals that facilitate them seem to ask very few questions, even when they are signing contracts and facilitating transactions that are deeply suspicious. In this case, the relocation contract was inflated hugely to over R600m and had very little if any supporting documentation. Yet, as amaBhungane's investigation notes, a registered auditor (Shaw) in capacity as a nominee director for BEX was happy to sign off on the transaction (Sole, 2018). 


\subsubsection{Lack of Accountability}

While calls to jail corrupt politicians have reached fever pitch (and rightly so), it is clear that corporations in South Africa and across the world have faced little scrutiny and accountability for their role in enabling grand corruption linked to state capture. None of the banks or other professionals discussed here have yet faced prosecution or sanction for their conduct. Moreover, the Zondo Commission of Inquiry has not yet summoned and interrogated these actors. In fact, the banks appearing at the Zondo Commission have only appeared to complain about alleged political interference, not to answer hard questions on their own complicity. This oversight must urgently be rectified. There is enough evidence in the public domain that demands the banks, auditors and consultants publicly account for their role in enabling theft of public money on a grand scale.

The absence of accountability is a result of several factors. There are deficiencies in South African and international law when it comes to corporate accountability. While banks do have extensive legal duties related to AML, their consistent failures do not result in sanction. This is largely because gutted state institutions, including law enforcement and prosecutors, lack the resources to investigate and prosecute often complex financial crimes. Further, professional bodies are clearly failing to hold their members accountable.

The veneer of legitimacy that is afforded bankers, lawyers and accountants conceals the pervasive role of the private sector in corruption. As a result, the nature of our discourse on corruption and state capture has tended to minimise and obscure the role played by these actors. The evidence increasingly shows that the global economy is shaped by these actors in such a way that fundamentally entrenches secrecy and enables criminality, all for the sake of profit.

\subsection{CONCLUSION}

South Africa now grapples with efforts to discover the causes of state capture in the country, and then to pursue accountability and restitution. These efforts will be undermined if they do not move the question of the private enablers of state capture from the margins to the centre of their analysis. Without accountability for the bankers, lawyers and accountants that have enabled and profited from grand corruption, new and old criminal networks alike are bound to continue to profit from their crimes. This requires law enforcement authorities to also include these kinds of prosecutions as priority cases.

The looting of Transnet is emblematic of this problem. Transnet was targeted because of its high capital expenditure, making its procurement a lucrative prize for the Gupta 
network. Further, Transnet executives and other public officials ignored their legal duties and chose to allow a group of private actors to profit at the expense of the South African public. Yet, all of the efforts of the Gupta enterprise would have gone to waste without a system of banks and shell companies that allowed them to move and hide their ill-gotten proceeds.

As we consider ways of strengthening institutions of the state, it is imperative to simultaneously demand stronger systems to ensure that corporations and private actors no longer enjoy impunity with regards to their role in plundering already limited and stretched public resources. While those actors often bemoan the current crisis, they have not been open about the way in which they profited from facilitating many of these crimes. Those implicated are not the exceptions to the rule. Rather, the enablers discussed here represent a systemic problem whereby secrecy and profit prevail at the expense of accountability and justice. 


\section{References}

amaBhungane \& Scorpio (2017) 'amaBhungane and Scorpio \#GuptaLeaks: Guptas and associates score R5.3bn in locomotives kickbacks', Daily Maverick. [Online]. https:// bit.ly/3s3xg Jw (Accessed 4 December 2019).

Anderson, K. (2017) 'Dubai: the Guptas' city of shells', Gupta-leaks.com. [Online]. https://bit. ly/31GJIxq (Accessed 4 December 2019).

Ballard, B. (2018) 'Top 5 biggest financial scandals of all time', World Finance. [Online]. https:// bit.ly/3Apdlrp (Accessed 4 December 2019).

Bezuidenhout, J. (2019) 'Reserve Bank official: 'It is unclear if, or how, Standard Bank missed the Gupta red flags', Daily Maverick. [Online]. https://bit.ly/3xwUMiS (Accessed 4 December 2019).

Bloomberg (2018) 'KPMG South Africa apologises for scandals, seeks second chance', BusinessTech. [Online]. https://bit.ly/ 3IDQILF (Accessed 4 December 2019).

Bullough, O. (2018) 'Britain lets Putin move his dark money with impunity. That has to stop', The Guardian. [Online]. https://bit. ly/3yuPaXO (Accessed 4 December 2019).

CIPC (2019) 'CIPC Company Search Records - Retrieved 22 March 2019 by Open Secrets', Open Secrets.

Cobham, A., Janský, P. \& Meinzer, M. (2015) ‘The Financial Secrecy Index: Shedding New Light on the Geography of Secrecy', Center for Global Development. CGD Working Paper 404. Washington, D.C. [Online]. https:// doi.org/10.2139/ssrn.2623152 (Accessed 4 December 2019).

Davies, R. (2017) 'HSBC shut down accounts linked to Gupta scandal', The Guardian. [Online]. https://bit.ly/37o3OEo (Accessed 4 December 2019).

FATF (2019) Definition of Money Laundering. [Online]. https://bit.ly/2VEPi8v (Accessed 4 December 2019).

Garcia-Bernardo, J., Fichtner, J., Takes, J.W. \& Heemskerk, E.M. (2017) 'Uncovering Offshore Financial Centers: Conduits and Sinks in the Global Corporate Ownership Network', Scientific Reports, 7(6246). [Online]. https://doi.org/10.1038/s41598017-06322-9
The International Consortium of Investigative Journalists (ICIJ) (2014) Luxembourg Leaks: Key Findings, International Consortium of Investigative Journalists (ICIJ). [Online]. https://bit.ly/3xpt2Ne (Accessed 4 December 2019).

Katz, A. (2019) 'The Cost of Dirty Money', Bloomberg. [Online]. https://bloom. bg/37o3Yvu (Accessed 4 December 2019).

Kaufmann, D. Hellman, J.S., Jones, G. \& Schankerman, M. (2000) Measuring governance, corruption, and state capture: How firms and bureaucrats shape the business environment in transition economies, World Bank Policy Research Working Paper, The World Bank. https://doi.org/10.1596/18139450-2312

Keefe, P.R. (2017) 'Why Corrupt Bankers Avoid Jail', The New Yorker. [Online]. https://bit.ly/ 3lC2TbP (Accessed 4 December 2019).

Khumalo, S. (2018) 'Gupta wedding under scrutiny as IRBA wraps up disciplinary of ex-KPMG auditor', Fin24. [Online]. https://bit.ly/3yrq4ZU (Accessed 4 December 2019).

McGregor, A. (2019) Advocacy: A call for disclosure of beneficial owners', amaBhungane. [Online]. https://bit. ly/31KDsor (Accessed 4 December 2019).

McKune, C., amaBhungane \& Thomson, W. (2018) 'Steinhoff's secret history and the dirty world of Markus Jooste', Financial Mail. [Online]. https://bit.ly/3lHCWaW (Accessed 4 December 2019).

Neale, D. (2019) 'Taking stock of 2018's money laundering scandals: When is enough enough? (Part 2)', Global Financial Integrity. [Online].https://bit.ly/3fFZJ2Q(Accessed 4 December 2019).

OCCRP (2017) The Russian Laundromat Exposed, Organized Crime and Corruption Reporting Project (OCCRP). [Online]. https://bit.ly/2X6Bpko (Accessed 4 December 2019).

OCCRP (2018) 'Danske Bank: 2018 Actor of the Year in Organised Crime and Corruption', Organized Crime and Corruption Reporting 
Project (OCCRP). [Online]. https://bitly/ 3lLLGwN (Accessed 4 December 2019).

Open Secrets (2018) The Bankers: Corporations and Economic Crime Report, Open Secrets. [Online].https://bit.ly/3jqEOC4 (Accessed 4 December 2019).

Pather, R. (2018) 'The state's case against the Guptas and co.', Mail \& Guardian. [Online]. https://bit.ly/2TYCklA (Accessed 4 December 2019).

Pillay, D. \& Prins, N. (2018) Transnet Inquiry Reference Book, State Capacity Research Project. Cape Town: Public Affairs Research Unit. [Online]. https://bit.ly/3rZK7w8

Radu, P. (2019) 'Vast Offshore Network Moved Billions With Help From Major Russian Bank', Organized Crime and Corruption Reporting Project (OCCRP). [Online].https://bit.ly/3CrfvIH (Accessed 4 December 2019).

Republic of South Africa (2001) 'Financial Intelligence Centre Act [No. 38 of 2001]', Government Gazette. Pretoria: The Presidency.

Schwartzkopff, F. (2019) 'Danske Bank not alone in world's biggest laundering scandal', Business Day. [Online]. https://bit.ly/3iuhDrl (Accessed 4 December 2019).

Sharife, K. (2017) 'Guptas, Big Banks Linked to South African-Chinese Locomotive Deal', Organized Crime and Corruption Reporting Project (OCCRP). [Online]. https://bit.ly/ 3rXOlV7 (Accessed 4 December 2019).

Sole, S. (2018) 'The "Gupta Minyan" and the R647-million Transnet scam', amaBhungane. [Online].https://bit.ly/3lGM7bq (Accessed 4 December 2019).

Stenhauser, G. \& Patrick, M. (2017) 'FROM THE WSJ: Guptas used HSBC accounts for transactions linked to suspected SA kickbacks', Business Day. [Online]. https://bit.ly/ 37qycxX (Accessed 4 December 2019).

Tax Justice Network (2018a) 'Financial Secrecy Index: Narrative Report on Hong Kong', Tax Justice Network: Financial Secrecy Index. [Online]. https://bit.ly/37sY2Bi (Accessed 4 December 2019).

Tax Justice Network (2018b) 'Financial Secrecy Index', Tax Justice Network: Financial Secrecy
Index. [Online]. https://bit.ly/3AnSJ2r (Accessed 4 December 2019).

Tequesta Group Limited (2015)

'Business Services Agreement No. CSRHK20150102359 - CSR HK \& Tequesta', Organized Crime and Corruption Reporting Project (OCCRP). [Online]. https://bitly/3Aj9FXT (Accessed 4 December 2019).

Transparency International UK (2017) Hiding in Plain Sight: How UK companies are used to launder the proceeds of corruption. [Online]. https://bit.ly/3AiHsAC

Tugendhaft Wapnick Banchetti \& Partners (2018) 'Letter from Russell Kantor to Susan Comrie (4 July 2018)', Daily Maverick. [Online]. https://bit.ly/3isHkZ3 (Accessed 4 December 2019).

Van der Does de Willebois, E., Halter, E.M., Harrison, R.A., Park, J.W. \& Sharman, J.C. (2017) 'The Puppet Masters: How the Corrupt Use Legal Structures to Hide Stolen Assets and What to Do About It', Stolen Asset Recovery Initiative. The International Bank for Reconstruction and Development/The World Bank. https://doi. org/10.1201/9781315155036-19

Van Vuuren, H. (2017) Apartheid guns and money: a tale of profit. Johannesburg: Jacana Media.

Van Zyl, G. (2017) 'Journos fly to Dubai in Gupta hunt: What they DIDN'T find will surprise you, BizNews. [Online]. https://bit.ly/ 37xAKKx (Accessed 4 December 2019).

Werksmans Attorneys (2017) Acqusition of 1064 locomotives for Transnet's general freight business, Organisation Undoing Tax Abuse (OUTA). [Online]. https://bit.ly/3IFAXnp

Yakovlev, E. \& Zhuravskaya, E. (2009) 'State Capture: From Yeltsin to Putin', Corruption, Development and Institutional Design. UK: Palgrave Macmillan. [Online]. https://doi. org/10.1057/9780230242173_2

Zondo Commission (2019) ‘Transcript from Inquiry into State Capture: Day 109 (10-06-2019) - Testimony of Shiwa Mazibuko, Commission of Inquiry into State Capture. https://bit.ly/2VAolDc 



\section{APPENDIX}

\begin{tabular}{|c|c|c|c|c|}
\hline $\begin{array}{l}\text { Case Study } \\
\text { in State } \\
\text { Capture }\end{array}$ & Status & Summary Description & $\begin{array}{l}\text { Investigation } \\
\text { Body / } \\
\text { Source of } \\
\text { Evidence }\end{array}$ & $\begin{array}{l}\text { Government } \\
\text { Entity } \\
\text { Implicated }\end{array}$ \\
\hline \multicolumn{5}{|c|}{ Scandals Connected to Jacob Zuma, Guptas, Other Key Networks and ANC Politics } \\
\hline $\begin{array}{l}\text { The State } \\
\text { of Capture } \\
\text { report - } \\
\text { focuses } \\
\text { on Guptas' } \\
\text { relationship } \\
\text { with Jacob } \\
\text { Zuma and } \\
\text { their alleged } \\
\text { influence on } \\
\text { the affairs } \\
\text { of state }\end{array}$ & $\begin{array}{l}\text { First complaint } \\
\text { was received } \\
\text { in March } 2016 \\
\text { and the report } \\
\text { was released in } \\
\text { November } 2016 .\end{array}$ & $\begin{array}{l}\text { Investigation into complaints of alleged improper } \\
\text { and unethical conduct by the President and } \\
\text { other State Functionaries, relating to alleged } \\
\text { improper relationships and involvement of the } \\
\text { Gupta Family in the removal and appointment } \\
\text { of Ministers and Directors of State-Owned } \\
\text { Enterprises (SOEs), resulting in improper and } \\
\text { possibly corrupt award of State Contracts and } \\
\text { Benefits to the Gupta Family's Businesses. } \\
\text { The report details numerous allegations of } \\
\text { the Guptas' involvement in affairs of the state } \\
\text { and their irregular activities that enable rent } \\
\text { extraction. The findings were not conclusive } \\
\text { and the remedial action was to establish a } \\
\text { commission of inquiry into state capture (to } \\
\text { be appointed by the President, but with a } \\
\text { judge selected by the Chief Justice). Litigation } \\
\text { endeavoured to delay or prohibit the report's } \\
\text { release and implementation of remedial actions, } \\
\text { but failed, and the commission was established } \\
\text { in } 2018 \text {. }\end{array}$ & $\begin{array}{l}\text { - Public } \\
\text { Protector, } \\
\text { followed by } \\
\text { litigation }\end{array}$ & $\begin{array}{l}\text { - GCIS (The } \\
\text { New Age) } \\
\text { - Eskom } \\
\text { (Optimum) } \\
\text { - Transnet } \\
\text { (Regiments/ } \\
\text { Trillian) } \\
\text { - Denel } \\
\text { - SAA (The } \\
\text { New Age) } \\
\text { - SABC (The } \\
\text { New Age) } \\
\text { - Department of } \\
\text { Finance } \\
\text { - Transport } \\
\text { (SAA) } \\
\text { - Communica- } \\
\text { tions (SABC } \\
\text { \& GCIS) }\end{array}$ \\
\hline $\begin{array}{l}\text { Zondo } \\
\text { Commission }\end{array}$ & $\begin{array}{l}\text { Established } \\
\text { in 2018, with } \\
\text { anticipated } \\
\text { conclusion being } \\
\text { the end of } 2021 .\end{array}$ & $\begin{array}{l}\text { Formally titled the Judicial Commission of } \\
\text { Inquiry into Allegations of State Capture, } \\
\text { Corruption and Fraud in the Public Sector } \\
\text { including Organs of State, the Commission } \\
\text { was promulgated by then President Zuma in } \\
\text { response to the remedial actions as outlined in } \\
\text { the Public Protector's State of Capture report. } \\
\text { As of June } 2021 \text {, the Commission that started } \\
\text { in August } 2018 \text { has held more than } 418 \text { days } \\
\text { of hearings of over } 330 \text { testimonies (generating } \\
\text { over } 71000 \text { pages of transcript). The inquiry's } \\
\text { terms of reference were expansive and, as } \\
\text { such, the scope of investigations went beyond } \\
\text { merely looking into the Gupta-related cases, } \\
\text { covering other networks (e.g., Bosasa) as well } \\
\text { as other government institutions (e.g., role } \\
\text { of Parliament). }\end{array}$ & $\begin{array}{l}\text { - Zondo } \\
\text { Commission }\end{array}$ & $\begin{array}{l}\text { Various } \\
\text { work-streams } \\
\text { covering } \\
\text { inter alia: } \\
\text { - SOEs } \\
\text { (Eskom, } \\
\text { Transnet, } \\
\text { Denel, SAA) } \\
\text { - Free State } \\
\quad \text { Provincial } \\
\text { Government } \\
\text { - Bosasa } \\
\text { - SARS } \\
\text { - Law } \\
\text { enforcement } \\
\text { - State Security } \\
\text { Agency (SSA) } \\
\text { - The New Age } \\
\text { \& ANN7 } \\
\text { - Role of } \\
\text { Parliament } \\
\text { and ANC }\end{array}$ \\
\hline
\end{tabular}




\begin{tabular}{|c|c|c|c|c|}
\hline $\begin{array}{l}\text { Case Study } \\
\text { in State } \\
\text { Capture }\end{array}$ & Status & Summary Description & $\begin{array}{l}\text { Investigation } \\
\text { Body / } \\
\text { Source of } \\
\text { Evidence }\end{array}$ & $\begin{array}{l}\text { Government } \\
\text { Entity } \\
\text { Implicated }\end{array}$ \\
\hline \multicolumn{5}{|c|}{ Scandals Connected to Jacob Zuma, Guptas, Other Key Networks and ANC Politics } \\
\hline Bosasa & $\begin{array}{l}\text { Dating back to a } \\
2009 \text { SIU report. } \\
\text { Investigations and } \\
\text { various litigations } \\
\text { are ongoing. }\end{array}$ & $\begin{array}{l}\text { In 2019, former Bosasa C00, Anglo Agrizzi, } \\
\text { testified at the Zondo Commission, detailing } \\
\text { the acts and long history of corruption between } \\
\text { various Bosasa companies predominantly } \\
\text { owned by Gavin Watson, and numerous } \\
\text { government entities/departments. The } \\
\text { testimony of Agrizzi (and other former Bosasa } \\
\text { employees) corroborated the findings of a } \\
2009 \text { SIU investigation that alleged corruption } \\
\text { in several contracts Bosasa had with the } \\
\text { Department of Correctional Services. Criminal } \\
\text { court proceedings have been initiated based } \\
\text { on the } 2009 \text { SIU investigation, along with new } \\
\text { investigations initiated by SARS and other law } \\
\text { enforcement entities. }\end{array}$ & $\begin{array}{l}\text { - Special } \\
\text { Investi- } \\
\text { gation } \\
\text { Unit (SIU) } \\
\text { - Zondo } \\
\text { Commission }\end{array}$ & $\begin{array}{l}\text { - Department of } \\
\text { Correctional } \\
\text { Services } \\
\text { - Department of } \\
\text { Justice } \\
\text { - Department of } \\
\text { Home Affairs } \\
\text { - Department of } \\
\text { Transport } \\
\text { - Various SOEs } \\
\text { (e.g., SAPO, } \\
\text { ACSA) } \\
\text { - National } \\
\text { Prosecuting } \\
\text { Authority } \\
\text { (NPA) } \\
\text { - Members of } \\
\text { Parliament }\end{array}$ \\
\hline Arms Deal & $\begin{array}{l}\text { Various } \\
\text { investigations and } \\
\text { sources, dating } \\
\text { back to 1990s. } \\
\text { Most significant } \\
\text { source being } \\
\text { through Seriti } \\
\text { Commission. } \\
\text { Corruption case } \\
\text { against Zuma is } \\
\text { ongoing. }\end{array}$ & $\begin{array}{l}\text { Commission of Inquiry into allegations of fraud, } \\
\text { corruption, impropriety, or irregularity in the } \\
\text { Strategic Defence Procurement Packages } \\
\text { (SDPP). Various court cases related to } \\
\text { allegations of corruption against Jacob Zuma. } \\
\text { On Monday, } 24 \text { October 2011, the President } \\
\text { announced the Commission chaired by Judge } \\
\text { Seriti. The findings of the Commission were that } \\
\text { there was "no evidence" of corruption, but this } \\
\text { is seen by many to have been a whitewash. The } \\
\text { report was taken on review and set aside in } \\
\text { August } 2019 \text {. The corruption case against Zuma } \\
\text { is ongoing before the courts. }\end{array}$ & $\begin{array}{l}\text { - Seriti } \\
\text { Commission } \\
\text { - Various } \\
\text { court cases }\end{array}$ & $\begin{array}{l}\text { Initially: } \\
\text { - South African } \\
\text { National } \\
\text { Defence } \\
\text { Force } \\
\text { - Members of } \\
\text { Parliament } \\
\text { Allegations also } \\
\text { involve: } \\
\text { - NPA } \\
\text { - SSA }\end{array}$ \\
\hline $\begin{array}{l}\text { Nkandla } \\
\text { Security } \\
\text { Upgrades }\end{array}$ & $\begin{array}{l}\text { Investigation } \\
\text { started in } \\
\text { November } 2012 . \\
\text { Report on } \\
\text { investigation } \\
\text { was released in } \\
\text { March } 2014 .\end{array}$ & $\begin{array}{l}\text { Report on security upgrades to President } \\
\text { Zuma's homestead in Nkandla. The investigation } \\
\text { found that the President unduly benefited from } \\
\text { the upgrades and as part of remedial actions } \\
\text { the President was required to pay back a portion } \\
\text { of the costs of the upgrades. Zuma instructed } \\
\text { that SAPS undertake their own investigation, } \\
\text { which sought to rationalise the expenses (fire- } \\
\text { pool report). Parliament accepted this alternative } \\
\text { report, but major court cases followed, } \\
\text { ultimately declaring that the Public Protector's } \\
\text { remedial actions are binding. President and } \\
\text { Parliament failed to uphold the Constitution. } \\
\text { President ordered to "pay back the money". }\end{array}$ & $\begin{array}{l}\text { - Public } \\
\text { Protector's } \\
\text { Secured } \\
\text { in Comfort } \\
\text { report, } \\
\text { followed by } \\
\text { litigation }\end{array}$ & 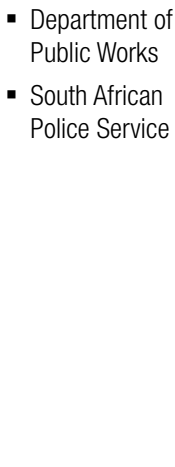 \\
\hline
\end{tabular}




\begin{tabular}{|c|c|c|c|c|}
\hline $\begin{array}{l}\text { Case Study } \\
\text { in State } \\
\text { Capture }\end{array}$ & Status & Summary Description & $\begin{array}{l}\text { Investigation } \\
\text { Body / } \\
\text { Source of } \\
\text { Evidence }\end{array}$ & $\begin{array}{l}\text { Government } \\
\text { Entity } \\
\text { Implicated }\end{array}$ \\
\hline \multicolumn{5}{|c|}{ Scandals Connected to Jacob Zuma, Guptas, Other Key Networks and ANC Politics } \\
\hline $\begin{array}{l}\text { Private } \\
\text { Aircraft } \\
\text { Landing at } \\
\text { Waterkloof } \\
\text { Airforce Base } \\
\text { and Gupta } \\
\text { Sun City } \\
\text { Wedding }\end{array}$ & May 2013. & $\begin{array}{l}\text { In 2013, justice, crime prevention, and } \\
\text { security cluster (JCPS) - a cabinet structure } \\
\text { composed of various ministries - undertook an } \\
\text { investigation into the Landing of a Commercial } \\
\text { aircraft at Air Force Base Waterkloof (report } \\
\text { titled the same). The investigation revealed that } \\
\text { the Guptas initially tried to organise a special } \\
\text { landing at OR Tambo International Airport, but } \\
\text { was turned down. They then approached the } \\
\text { Indian High Commission who re-designated the } \\
\text { wedding entourage as an official delegation to } \\
\text { secure a landing at the Waterkloof base. The } \\
\text { wedding held at Sun City was attended by a } \\
\text { number of high-profile ANC politicians and was } \\
\text { paid for in part by moneys looted from the Vrede } \\
\text { Dairy Farm project. }\end{array}$ & $\begin{array}{l}\text { - Report by } \\
\text { JPCS } \\
\text { - Zondo } \\
\text { Commission }\end{array}$ & $\begin{array}{l}\text { - Department of } \\
\text { International } \\
\text { Relations and } \\
\text { Cooperation } \\
\text { (DIRCO) } \\
\text { - Department of } \\
\text { Defence } \\
\text { - Department of } \\
\text { Transport }\end{array}$ \\
\hline $\begin{array}{l}\text { Free State } \\
\text { Provincial } \\
\text { Capture, } \\
\text { includes } \\
\text { Vrede Dairy } \\
\text { Farm and } \\
\text { Asbestos } \\
\text { Contracts }\end{array}$ & Ongoing. & $\begin{array}{l}\text { The Vrede Dairy Farm project was initiated } \\
\text { by the Free State Provincial Government as a } \\
\text { development project, however, in partnering with } \\
\text { a Gupta-linked company Estina, government } \\
\text { funds were looted. In 2018, the Public } \\
\text { Protector released a report on their } 2018 \\
\text { investigation, but it was taken on review and } \\
\text { set aside by the courts. The second part of the } \\
\text { investigation is yet to be finalised. The NPA } \\
\text { laid criminal charges against Gupta associates } \\
\text { and implicated government officials. Court } \\
\text { proceedings are ongoing. } \\
\text { Significant testimony and evidence have been } \\
\text { presented at the Zondo Commission regarding } \\
\text { the Vrede Farm case, as well as the asbestos } \\
\text { inspection project (criminal proceedings are also } \\
\text { underway). Both projects implicate high-profile } \\
\text { politicians and senior officials manipulating } \\
\text { government process. }\end{array}$ & $\begin{array}{l}\text { - } \text { Public } \\
\text { Protector } \\
\text { reports } \\
\text { - Zondo } \\
\text { Commission } \\
\text { - Various } \\
\text { court cases }\end{array}$ & $\begin{array}{l}\text { - Free State } \\
\text { Provincial } \\
\text { Government }\end{array}$ \\
\hline $\begin{array}{l}\text { Irregular } \\
\text { removal of } \\
\text { National } \\
\text { Director } \\
\text { of Public } \\
\text { Prosecutions } \\
\text { (NDPP), } \\
\text { Mxolisi } \\
\text { Nxasana }\end{array}$ & $\begin{array}{l}\text { Inquiry instituted } \\
\text { in February } 2015, \\
\text { but was cancelled } \\
\text { in May } 2015 . \\
\text { This triggers the } \\
\text { Constitutional Court } \\
\text { cases that followed. }\end{array}$ & $\begin{array}{l}\text { Inquiry into the fitness of Mxolisi Nxasana to } \\
\text { hold office as NDPP. The Inquiry was cancelled } \\
\text { after Zuma "agreed to let Nxasana resign". He } \\
\text { was paid R17m - the balance of his ten-year } \\
\text { contract. Court cases followed detailing the } \\
\text { abuse of the presidency powers by Zuma. } \\
\text { Ultimately, Nxasana was ordered to repay } \\
\text { R17m and Zuma's appointed replacement, } \\
\text { Shawn Abrahams, was ordered to vacate office. } \\
\text { Constitutional Court found Zuma's actions to } \\
\text { be an abuse of power and in breach of his } \\
\text { constitutional obligations. }\end{array}$ & $\begin{array}{l}\text { - Cassim } \\
\text { Inquiry into } \\
\text { fitness of } \\
\text { Mxolisi } \\
\text { Nxasana to } \\
\text { hold office } \\
\text { of NDPP } \\
\text { initiated } \\
\text { by Zuma, } \\
\text { followed by } \\
\text { litigation }\end{array}$ & $\begin{array}{l}\text { - National } \\
\text { Prosecution } \\
\text { Authority }\end{array}$ \\
\hline $\begin{array}{l}\text { Political } \\
\text { killings in } \\
\text { KZN }\end{array}$ & $\begin{array}{l}\text { Established in } \\
\text { October } 2016 . \text { The } \\
\text { report was released } \\
\text { in May } 2018 .\end{array}$ & $\begin{array}{l}\text { On } 28 \text { October 2016, the Premier of the } \\
\text { Province of KwaZulu-Natal established a } \\
\text { Commission of Enquiry into the Underlying } \\
\text { Causes of the Murder of Politicians in KwaZulu- } \\
\text { Natal (KZN). }\end{array}$ & $\begin{array}{l}\text { - Moerane } \\
\text { Commission } \\
\text { of Enquiry }\end{array}$ & $\begin{array}{l}\text { - KZN Provincial } \\
\text { Government } \\
\text { - KZN Local } \\
\text { Governments }\end{array}$ \\
\hline
\end{tabular}




\begin{tabular}{|c|c|c|c|c|}
\hline $\begin{array}{l}\text { Case Study } \\
\text { in State } \\
\text { Capture }\end{array}$ & Status & Summary Description & $\begin{array}{l}\text { Investigation } \\
\text { Body / } \\
\text { Source of } \\
\text { Evidence } \\
\end{array}$ & $\begin{array}{l}\text { Government } \\
\text { Entity } \\
\text { Implicated }\end{array}$ \\
\hline \multicolumn{5}{|c|}{ Scandals Connected to Jacob Zuma, Guptas, Other Key Networks and ANC Politics } \\
\hline \multicolumn{5}{|c|}{ State Capture of State-Owned Enterprises and Government Departments } \\
\hline $\begin{array}{l}\text { Interference } \\
\text { in operations } \\
\text { at the SABC }\end{array}$ & $\begin{array}{l}\text { The Ad Hoc } \\
\text { Committee was } \\
\text { established in } \\
\text { November } 2016 \\
\text { and final report } \\
\text { was tabled on } \\
24 \text { February } 2017 .\end{array}$ & $\begin{array}{l}\text { Parliamentary Ad Hoc Committee on the } \\
\text { SABC Board Inquiry into mismanagement and } \\
\text { interference in SABC operations. Findings } \\
\text { include evidence of Minister Faith Muthambi's } \\
\text { interference in the organisation and editorial } \\
\text { interference, in the firing of SABC } 8 \text { who } \\
\text { protested censorship of the national broadcaster } \\
\text { (on instruction from COO Hlaudi Motsoeneng). It } \\
\text { should be noted that the inquiry was preceded } \\
\text { by an investigation by the Public Protector. } \\
\text { Details are contained in the } 2014 \text { report titled } \\
\text { When Governance and Ethics Fail. }\end{array}$ & $\begin{array}{l}\text { - Parliamen- } \\
\text { tary Inquiry } \\
\text { - Preceded by } \\
\text { an investi- } \\
\text { gation by } \\
\text { the Public } \\
\text { Protector }\end{array}$ & $\begin{array}{l}\text { - SABC } \\
\text { (Department } \\
\text { of Communi- } \\
\text { cation) }\end{array}$ \\
\hline \multirow[t]{2}{*}{$\begin{array}{l}\text { Passenger } \\
\text { Rail Agency } \\
\text { of South } \\
\text { Africa } \\
\text { (PRASA) }\end{array}$} & $\begin{array}{l}\text { Complaints were } \\
\text { lodged in } 2012 \\
\text { and the report } \\
\text { was released in } \\
\text { August } 2015 .\end{array}$ & $\begin{array}{l}\text { Several cases of "mismanagement and } \\
\text { irregularities" regarding various contracts. } \\
\text { Lucky Montana was CEO at the time. One of } \\
\text { the remedial actions stipulated that National } \\
\text { Treasury was to investigate all PRASA contracts } \\
\text { from } 2012 \text { onwards with a value of R10 million } \\
\text { or more. National Treasury implemented the } \\
\text { remedial action which resulted in several } \\
\text { investigations, the details of which were leaked } \\
\text { to the public. }\end{array}$ & $\begin{array}{l}\text { - Public } \\
\text { Protector's } \\
\text { Derailed } \\
\text { report on } \\
\text { PRASA } \\
\text { - Numerous } \\
\text { investiga- } \\
\text { tions }\end{array}$ & $\begin{array}{l}\text { - PRASA } \\
\text { - Department of } \\
\text { Transport }\end{array}$ \\
\hline & $\begin{array}{l}\text { In June } 2017, \\
\text { Parliament directed } \\
4 \text { committees to } \\
\text { investigate state } \\
\text { capture. Committee } \\
\text { hearings were not } \\
\text { completed. }\end{array}$ & $\begin{array}{l}\text { In terms of the parliamentary directive, the } \\
\text { Portfolio Committee on Transport was requested } \\
\text { to establish an Inquiry into State Capture at } \\
\text { PRASA. However, the Portfolio Committee noted } \\
\text { that PRASA was not mentioned in the Public } \\
\text { Protector's State of Capture report and decided } \\
\text { they would focus on the various investigation } \\
\text { reports produced for National Treasury (as } \\
\text { recommended in Derailed report). }\end{array}$ & $\begin{array}{l}\text { - Portfolio } \\
\text { Committee } \\
\text { on Transport }\end{array}$ & $\begin{array}{l}\text { - PRASA } \\
\text { - Department of } \\
\text { Transport }\end{array}$ \\
\hline $\begin{array}{l}\text { Eskom } \\
\text { Inquiry into } \\
\text { State Capture }\end{array}$ & $\begin{array}{l}\text { In June } 2017 \text {, } \\
\text { Parliament directed } \\
4 \text { committees } \\
\text { to investigate } \\
\text { state capture. } \\
\text { Public Enterprises } \\
\text { Committee } \\
\text { report on Eskom } \\
\text { was released in } \\
\text { November } 2018 .\end{array}$ & $\begin{array}{l}\text { Extensive hearings were held by the Committee } \\
\text { detailing much of the evidence presented in } \\
\text { the Public Protector's report. The Committee } \\
\text { presented recommendations and compiled } \\
\text { a final report detailing their findings. These } \\
\text { included findings that Ministers Lynne Brown } \\
\text { and Malusi Gigaba were negligent and had to } \\
\text { be held accountable. Also recommended that } \\
\text { criminal investigations be undertaken against } \\
\text { the relevant Eskom executives. }\end{array}$ & $\begin{array}{l}\text { - Parliamen- } \\
\text { tary Inquiry }\end{array}$ & $\begin{array}{l}\text { - Eskom } \\
\text { - Department } \\
\text { of Public } \\
\text { Enterprises }\end{array}$ \\
\hline $\begin{array}{l}\text { Nugent } \\
\text { Commission } \\
\text { - SARS } \\
\text { Inquiry }\end{array}$ & $\begin{array}{l}\text { The Inquiry was } \\
\text { constituted on } \\
24 \text { May } 2018 \text { and } \\
\text { the final report } \\
\text { was released in } \\
\text { December } 2018 .\end{array}$ & $\begin{array}{l}\text { Commission of Inquiry into tax administration } \\
\text { and governance by South African Revenue } \\
\text { Service (SARS). Tom Moyane was fired based on } \\
\text { the interim report released in September } 2018 . \\
\text { The inquiry found that Moyane, with the help of } \\
\text { consultancy company Bain, had implemented } \\
\text { restructuring of the organisation, resulting in } \\
\text { gross mismanagement and erosion of SARS. } \\
\text { Moyane motivated the restructuring based on } \\
\text { the "rogue unit" narrative that has been the } \\
\text { subject of several other debunked investigations } \\
\text { and the subject of much litigation. }\end{array}$ & $\begin{array}{l}\text { - Judicial } \\
\text { Commission } \\
\text { of Inquiry } \\
\text { - Court cases } \\
\text { around the } \\
\text { "rogue unit" } \\
\text { narrative }\end{array}$ & $\begin{array}{l}\text { - SARS } \\
\text { (National } \\
\text { Treasury) }\end{array}$ \\
\hline
\end{tabular}




\begin{tabular}{|c|c|c|c|c|}
\hline $\begin{array}{l}\text { Case Study } \\
\text { in State } \\
\text { Capture }\end{array}$ & Status & Summary Description & $\begin{array}{l}\text { Investigation } \\
\text { Body / } \\
\text { Source of } \\
\text { Evidence }\end{array}$ & $\begin{array}{l}\text { Government } \\
\text { Entity } \\
\text { Implicated }\end{array}$ \\
\hline \multicolumn{5}{|c|}{ Scandals Connected to Jacob Zuma, Guptas, Other Key Networks and ANC Politics } \\
\hline \multicolumn{5}{|c|}{ State Capture of State-Owned Enterprises and Government Departments } \\
\hline $\begin{array}{l}\text { Commission } \\
\text { of Inquiry } \\
\text { into Public } \\
\text { Investment } \\
\text { Corporation } \\
\text { (PIC) }\end{array}$ & $\begin{array}{l}\text { In October } 2018 \text {, } \\
\text { the Commission } \\
\text { was constituted, } \\
\text { and the final report } \\
\text { was released in } \\
\text { March } 2020 .\end{array}$ & $\begin{array}{l}\text { Commission of Inquiry into allegations of } \\
\text { impropriety regarding Public Investment } \\
\text { Corporation (PIC). There were extensive hearings } \\
\text { on various 'dodgy' deals the PIC entered } \\
\text { into and details of political and executive } \\
\text { interference in the operations and decision- } \\
\text { making processes of the investment agency. }\end{array}$ & $\begin{array}{l}\text { - Judicial } \\
\text { Commission } \\
\text { of Inquiry }\end{array}$ & $\begin{array}{l}\text { - PIC (National } \\
\text { Treasury) }\end{array}$ \\
\hline $\begin{array}{l}\text { South African } \\
\text { Social } \\
\text { Security } \\
\text { Agency } \\
\text { (SASSA) }\end{array}$ & $\begin{array}{l}\text { Various } \\
\text { Constitutional Court } \\
\text { cases from } 2011 \\
\text { to } 2018 \text { resulted } \\
\text { in removal of CPS } \\
\text { as service provider } \\
\text { to SASSA. }\end{array}$ & $\begin{array}{l}\text { In 2014, South African Social Security Agency's } \\
\text { (SASSA) } 2012 \text { contract with CPS was found } \\
\text { to be irregular and invalid, however, due to the } \\
\text { importance of ensuring beneficiaries received } \\
\text { grants, CPS continued to be the service } \\
\text { providers until } 2018 \text {. Following a March } 2017 \\
\text { ruling, the Constitutional Court instituted a } \\
\text { Section } 38 \text { Inquiry into Minister Bathabile } \\
\text { Dlamini's personal liability for the narrowly } \\
\text { averted grant payment crisis. }\end{array}$ & $\begin{array}{l}\text { Primary } \\
\text { sources: } \\
\text { - AllPay court } \\
\text { case } \\
\text { - Black Sash } \\
\text { court case }\end{array}$ & - SASSA \\
\hline $\begin{array}{l}\text { South African } \\
\text { Airways (SAA) } \\
\text { and SAA } \\
\text { Technical }\end{array}$ & $\begin{array}{l}\text { Court case } \\
\text { to have Dudu } \\
\text { Myeni declared a } \\
\text { delinquent director } \\
\text { was launched } \\
\text { in } 2017 .\end{array}$ & $\begin{array}{l}\text { Court case was launched in } 2017 \text { by Outa and } \\
\text { the SAA Pilots' Association (SAAPA) to declare } \\
\text { Myeni a delinquent director in terms of the } \\
\text { Companies Act, based on her actions while she } \\
\text { was chairperson of the SAA Board. In 2020, the } \\
\text { High Court declared Myeni a delinquent director } \\
\text { for life. A significant amount of new evidence } \\
\text { also emerged through the Zondo Commission, } \\
\text { outlining how the operations at SAA were } \\
\text { undermined and how Myeni and others abused } \\
\text { their positions of authority. }\end{array}$ & $\begin{array}{l}\text { - Court } \\
\text { papers } \\
\text { - Zondo } \\
\text { Commission }\end{array}$ & $\begin{array}{l}\text { - SAA } \\
\text { - SAA Technical }\end{array}$ \\
\hline $\begin{array}{l}\text { Gupta Family } \\
\text { Naturalisation }\end{array}$ & $\begin{array}{l}\text { In June } 2017, \\
\text { Parliament directed } \\
4 \text { committees to } \\
\text { investigate state } \\
\text { capture. Final } \\
\text { report was tabled } \\
14 \text { March } 2019 .\end{array}$ & $\begin{array}{l}\text { Portfolio Committee on Home Affairs Inquiry into } \\
\text { the Gupta Family Naturalisation was established } \\
\text { in terms of the Parliamentary directive. Hearings } \\
\text { formally started on } 12 \text { September 2018. Final } \\
\text { report was tabled on } 14 \text { March 2019. Questions } \\
\text { were raised around contracts with Visa } \\
\text { Facilitation Services. This matter is ongoing as } \\
\text { of December } 2020 \text {. }\end{array}$ & $\begin{array}{l}\text { - Portfolio } \\
\text { Committee } \\
\text { on Home } \\
\text { Affairs }\end{array}$ & $\begin{array}{l}\text { - Department of } \\
\text { Home Affairs }\end{array}$ \\
\hline $\begin{array}{l}\text { Inquiry into } \\
\text { State Capture } \\
\text { related to } \\
\text { Gupta-owned } \\
\text { mines }\end{array}$ & $\begin{array}{l}\text { In June } 2017, \\
\text { Parliament directed } \\
4 \text { committees } \\
\text { to investigate } \\
\text { state capture. }\end{array}$ & $\begin{array}{l}\text { Though the Committee drafted a term of } \\
\text { reference for the Inquiry, the activities of holding } \\
\text { hearings and consolidating the evidence never } \\
\text { materialised beyond questions being put to then } \\
\text { Minister Zwane. }\end{array}$ & $\begin{array}{l}\text { - Portfolio } \\
\text { Committee } \\
\text { on Mineral } \\
\text { Resources }\end{array}$ & $\begin{array}{l}\text { - Department } \\
\text { of Mineral } \\
\text { Resources }\end{array}$ \\
\hline
\end{tabular}




\begin{tabular}{|c|c|c|c|c|}
\hline $\begin{array}{l}\text { Case Study } \\
\text { in State } \\
\text { Capture }\end{array}$ & Status & Summary Description & $\begin{array}{l}\text { Investigation } \\
\text { Body / } \\
\text { Source of } \\
\text { Evidence }\end{array}$ & $\begin{array}{l}\text { Government } \\
\text { Entity } \\
\text { Implicated }\end{array}$ \\
\hline \multicolumn{5}{|c|}{ Scandals Connected to Jacob Zuma, Guptas, Other Key Networks and ANC Politics } \\
\hline \multicolumn{5}{|c|}{ State Capture of State-Owned Enterprises and Government Departments } \\
\hline \multirow{3}{*}{$\begin{array}{l}\text { Various } \\
\text { investigations } \\
\text { relating to } \\
\text { State Capture } \\
\text { at Eskom }\end{array}$} & 2015 & $\begin{array}{l}\text { In 2015, Dentons produced an interim report } \\
\text { on their investigations into Status of Business } \\
\text { and Challenges at Eskom. Their investigation } \\
\text { was halted. }\end{array}$ & - Eskom & - Eskom \\
\hline & \multirow[t]{2}{*}{2017} & $\begin{array}{l}\text { In 2017, PricewaterhouseCoopers (PwC) was } \\
\text { appointed by National Treasury to investigate } \\
\text { Eskom's Coal Procurement Processes. Damning } \\
\text { findings were made in relation to Gupta-owned } \\
\text { Tegeta mine contracts and poor coal quality. }\end{array}$ & - Eskom & - Eskom \\
\hline & & $\begin{array}{l}\text { G9 was contracted by Eskom to investigate } \\
\text { the Trillian/McKinsey contracts. Interim report } \\
\text { presented to Board of Eskom in August } 2017 . \\
\text { The investigation remained incomplete, and } \\
\text { no report is available in the public domain. } \\
\text { Evidence from the investigation was presented } \\
\text { in the Parliamentary Inquiry into Eskom } \\
\text { State Capture. }\end{array}$ & $\begin{array}{l}\text { - National } \\
\text { Treasury }\end{array}$ & - Eskom \\
\hline $\begin{array}{l}\text { National } \\
\text { Treasury } \\
\text { Fundudzi } \\
\text { reports, } \\
\text { related to } \\
\text { Eskom and } \\
\text { Transnet (x3) }\end{array}$ & $\begin{array}{l}\text { Final reports } \\
\text { compiled in } \\
\text { November } 2018 \\
\text { and released to } \\
\text { the public shortly } \\
\text { thereafter. }\end{array}$ & $\begin{array}{l}\text { Investigations requested by National Treasury } \\
\text { of alleged corruption at Transnet and Eskom. } \\
\text { The three reports focused on Eskom (general), } \\
\text { the contracts related to Trillian/McKinsey and } \\
\text { Transnet Locomotives. }\end{array}$ & $\begin{array}{l}\text { - National } \\
\text { Treasury } \\
\text { Fundudzi }\end{array}$ & $\begin{array}{l}\text { - Eskom } \\
\text { - Transnet }\end{array}$ \\
\hline \multirow[t]{2}{*}{$\begin{array}{l}\text { Transnet } \\
\text { Locomotive } \\
\text { Contracts }\end{array}$} & \multirow[t]{2}{*}{$\begin{array}{l}\text { Investigations } \\
\text { commenced in } \\
\text { December } 2017 \\
\text { and reports on } \\
\text { findings submitted } \\
\text { during } 2018 .\end{array}$} & $\begin{array}{l}\text { Werksmans Attorneys was appointed in } \\
\text { December } 2017 \text { to undertake an investigation } \\
\text { into the } 1064 \text { Transnet Locomotives } \\
\text { procurement process, however, the investigation } \\
\text { was halted. No report in the public domain. }\end{array}$ & - Werksmans & - Transnet \\
\hline & & $\begin{array}{l}\text { Mncedisi Ndlovu \& Sedumedi (MNS) Attorneys } \\
\text { was then appointed to investigate } 1064 \\
\text { locomotives procurement process. The report } \\
\text { is not in the public domain, but media indicates } \\
\text { that recommendations mirror the Werksmans' } \\
\text { findings and recommends that Molefe face } \\
\text { criminal charges. }\end{array}$ & $\begin{array}{l}\text { - Mncedisi } \\
\text { Ndlovu \& } \\
\text { Sedumedi }\end{array}$ & - Transnet \\
\hline $\begin{array}{l}\text { Inquiry into } \\
\text { State Capture } \\
\text { at Transnet } \\
\text { and Denel }\end{array}$ & $\begin{array}{l}\text { In June } 2017, \\
\text { Parliament directed } \\
4 \text { committees to } \\
\text { investigate state } \\
\text { capture. Committee } \\
\text { hearings were not } \\
\text { completed. }\end{array}$ & $\begin{array}{l}\text { A detailed information booklet was prepared } \\
\text { in relation to Transnet, however, hearings were } \\
\text { not held before the end of term of Parliament. } \\
\text { Following National elections in 2019, it } \\
\text { was decided that outstanding Inquiries into } \\
\text { state capture be postponed indefinitely until } \\
\text { conclusion of the Zondo Commission. }\end{array}$ & $\begin{array}{l}\text { - Portfolio } \\
\text { Committee } \\
\text { on Public } \\
\text { Enterprises }\end{array}$ & $\begin{array}{l}\text { - Transnet } \\
\text { - Denel }\end{array}$ \\
\hline
\end{tabular}




\begin{tabular}{|c|c|c|c|c|}
\hline $\begin{array}{l}\text { Case Study } \\
\text { in State } \\
\text { Capture }\end{array}$ & Status & Summary Description & $\begin{array}{l}\text { Investigation } \\
\text { Body / } \\
\text { Source of } \\
\text { Evidence }\end{array}$ & $\begin{array}{l}\text { Government } \\
\text { Entity } \\
\text { Implicated }\end{array}$ \\
\hline \multicolumn{5}{|c|}{ Scandals Connected to Jacob Zuma, Guptas, Other Key Networks and ANC Politics } \\
\hline \multicolumn{5}{|c|}{ Law Enforcement and the Security Cluster } \\
\hline $\begin{array}{l}\text { Enquiry into } \\
\text { Jiba and } \\
\text { Mrwebi's } \\
\text { fitness to } \\
\text { hold office } \\
\text { at NPA }\end{array}$ & $\begin{array}{l}\text { Established in } \\
\text { November } 2018 . \\
\text { Report was issued } \\
\text { in April } 2019 .\end{array}$ & $\begin{array}{l}\text { Presidential Enquiry into the fitness to hold } \\
\text { office of suspended NPA senior advocates } \\
\text { Nomgcobo Jiba and Lawrence Mrwebi. NPA's } \\
\text { deputy head Jiba, and Mrwebi, the head of } \\
\text { the Specialised Commercial Crimes Unit, were } \\
\text { suspended in October } 2018 \text { by President Cyril } \\
\text { Ramaphosa. The Inquiry was headed by retired } \\
\text { Constitutional Court Justice Yvonne Mokgoro. } \\
\text { Jiba and Mrwebi were accused of improper } \\
\text { conduct in their handling of cases involving } \\
\text { former crime intelligence head Richard Mdluli, } \\
\text { as well as former KwaZulu-Natal Hawks boss } \\
\text { Johan Booysen. }\end{array}$ & $\begin{array}{c}\text { - Mokgoro } \\
\text { Enquiry }\end{array}$ & $\begin{array}{l}\text { - } \text { National } \\
\text { Prosecuting } \\
\text { Authority }\end{array}$ \\
\hline $\begin{array}{l}\text { High-Level } \\
\text { Review Panel } \\
\text { on the State } \\
\text { Security } \\
\text { Agency (SSA) }\end{array}$ & $\begin{array}{l}\text { Established in June } \\
2018 \text { and final } \\
\text { report was sent to } \\
\text { the President in } \\
\text { December } 2018 .\end{array}$ & $\begin{array}{l}\text { The High-Level Review Panel into the SSA } \\
\text { was established by President Ramaphosa in } \\
\text { June 2018. The key finding was a serious } \\
\text { politicisation and factionalisation of the } \\
\text { intelligence community over the past decade } \\
\text { or more. This resulted in "an almost complete } \\
\text { disregard for the Constitution, policy, legislation } \\
\text { and other prescripts, and [turned] our civilian } \\
\text { intelligence community into a private resource } \\
\text { to serve the political and personal interests of } \\
\text { particular individuals" (High-Level Review Panel } \\
\text { on the SSA, 2018, p.ii). }\end{array}$ & $\begin{array}{l}\text { - Review } \\
\text { Panel } \\
\text { established } \\
\text { by President } \\
\text { Ramaphosa }\end{array}$ & - SSA \\
\hline $\begin{array}{l}\text { Various court } \\
\text { cases against } \\
\text { persons } \\
\text { within law } \\
\text { enforcement }\end{array}$ & Ongoing. & $\begin{array}{l}\text { Though testimony and evidence have been } \\
\text { presented at the Zondo Commission, it is } \\
\text { understood that no definitive findings will be } \\
\text { made regarding the capture of law enforcement } \\
\text { under the Zuma administration. Since } 2012 \\
\text { onwards, there were several court cases } \\
\text { that were pursued against individuals in law } \\
\text { enforcement, all of which have been either } \\
\text { dismissed or withdrawn. Most noteworthy are } \\
\text { the cases involved, amongst others: Anwa } \\
\text { Dramat and Shadrack Sibiya of the Hawks } \\
\text { (and Robert McBride from Independent Police } \\
\text { Investigative Directorate [IPID]) for allegations } \\
\text { related to the "Zimbabwean rendition" matter; } \\
\text { Johan Booysen for alleged racketeering as part } \\
\text { of "Cato Manor hit squad"; and the various } \\
\text { senior officials accused of being part of the } \\
\text { "rogue" intelligence unit at SARS. Other court } \\
\text { cases that have provided significant evidence } \\
\text { indicating the capture of law enforcement relate } \\
\text { to the irregular appointed allies of the Shadow } \\
\text { State capture network or the irrational removal } \\
\text { of potential opponents holding senior positions } \\
\text { in law enforcement. Example is the irregular } \\
\text { removal of Mxolisi Nxasana as National Director } \\
\text { of Public Prosecutions (NDPP). }\end{array}$ & $\begin{array}{l}\text { - Various } \\
\text { court cases, } \\
\text { proceedings } \\
\text { in Parlia- } \\
\text { ment } \\
\text { - Zondo } \\
\text { Commission }\end{array}$ & $\begin{array}{l}\text { - NPA } \\
\text { - SAPS } \\
\text { - Hawks } \\
\text { - IPID }\end{array}$ \\
\hline
\end{tabular}




\begin{tabular}{|c|c|c|c|c|}
\hline $\begin{array}{l}\text { Case Study } \\
\text { in State } \\
\text { Capture }\end{array}$ & Status & Summary Description & $\begin{array}{l}\text { Investigation } \\
\text { Body / } \\
\text { Source of } \\
\text { Evidence }\end{array}$ & $\begin{array}{l}\text { Government } \\
\text { Entity } \\
\text { Implicated }\end{array}$ \\
\hline \multicolumn{5}{|c|}{ Scandals Connected to Jacob Zuma, Guptas, Other Key Networks and ANC Politics } \\
\hline \multicolumn{5}{|c|}{ Investigations concerning Private Sector } \\
\hline $\begin{array}{l}\text { Budlender } \\
\text { report on } \\
\text { Trillian }\end{array}$ & $\begin{array}{l}\text { Released in } \\
\text { June } 2017 .\end{array}$ & $\begin{array}{l}\text { Trillian Holdings Board appointed Geoff } \\
\text { Budlender SC to undertake investigations into } \\
\text { State Capture allegations at Trillian Capital. } \\
\text { Detailed accounts from whistle-blowers } \\
\text { highlighted how information was withheld by } \\
\text { senior management at Trillian. }\end{array}$ & - Trillion & - Eskom \\
\hline $\begin{array}{l}\text { Collapse of } \\
\text { VBS Mutual } \\
\text { Bank }\end{array}$ & $\begin{array}{l}\text { Investigation } \\
\text { launched in } \\
\text { April } 2018 \text { and } \\
\text { the report was } \\
\text { released in } \\
\text { October } 2018 .\end{array}$ & $\begin{array}{l}\text { Minister of Finance placed VBS under } \\
\text { curatorship with effect from } 11 \text { March 2018. In } \\
\text { April 2018, the Deputy Governor of the South } \\
\text { African Reserve Bank instituted an investigation } \\
\text { into VBS. The outcomes of the investigation } \\
\text { showed blatant fraud and corruption by senior } \\
\text { executives/Board and how they extracted } \\
\text { money from the bank. Municipal funds were } \\
\text { illegally deposited with VBS (senior ANC and } \\
\text { EFF politicians have been implicated). }\end{array}$ & $\begin{array}{l}\text { - SARB } \\
\text { investiga- } \\
\text { tion report } \\
\text { VBS Mutual } \\
\text { Bank - The } \\
\text { Great Bank } \\
\text { Heist }\end{array}$ & $\begin{array}{l}\text { - Several } \\
\text { Provincial and } \\
\text { Municipal } \\
\text { Officials } \\
\text { (Limpopo } \\
\text { Government) } \\
\text { - SOEs } \\
\text { (particularly } \\
\text { PRASA) }\end{array}$ \\
\hline $\begin{array}{l}\text { SA Institute } \\
\text { of Chartered } \\
\text { Accountants' } \\
\text { (SAICA) } \\
\text { investigation } \\
\text { into KPMG }\end{array}$ & $\begin{array}{l}\text { Final report was } \\
\text { handed to SAICA in } \\
\text { December } 2018 .\end{array}$ & $\begin{array}{l}\text { SA Institute of Chartered Accountants (SAICA) } \\
\text { established an Inquiry to investigate state } \\
\text { capture related allegations of misconduct of its } \\
\text { members who worked for KPMG. The Inquiry } \\
\text { chaired by advocate Dumisa Ntsebeza held } \\
\text { public hearings and handed its final report to } \\
\text { SAICA in December 2018. Indications are that } \\
\text { the final report will not be made public until all } \\
\text { investigations and disciplinary hearings have } \\
\text { been finalised. }\end{array}$ & - SAICA & - Guptas \\
\hline Bell Pottinger & $\begin{array}{l}2017 \text { investigation } \\
\text { by PRCA. }\end{array}$ & $\begin{array}{l}\text { In 2016, the Guptas appointed British PR } \\
\text { company, Bell Pottinger, who developed and } \\
\text { promoted a campaign that underpinned the RET } \\
\text { and WMC narratives. In 2017, there was an } \\
\text { independent law firm review by Herbert Smith } \\
\text { Freehills resulting in Bell Pottinger's expulsion } \\
\text { from the Public Relations and Communications } \\
\text { Association (PRCA). }\end{array}$ & $\begin{array}{l}\text { - PRCA } \\
\text { - GuptaLeaks } \\
\text { - Ongoing } \\
\text { research } \\
\text { on disinfor- } \\
\text { mation }\end{array}$ & - Guptas \\
\hline
\end{tabular}

